\title{
ANALISIS KELAYAKAN PENDIRIAN USAHA NUGGET IKAN BANDENG DENGAN METODE NET PRESENT VALUE (NPV) DI KABUPATEN MAROS
}

\author{
${ }^{1)}$ Suradi, ${ }^{2)}$ Andi Haslindah, ${ }^{3)}$ Jamilah \\ ${ }^{1,2)}$ Dosen Program StudiTeknikIndustri Fakultas Teknik Universitas Islam Makassar \\ ${ }^{3)}$ Mahasiswi Program Studi Teknik Industri Universitas Islam Makassar \\ Jl. Perintis Kemerdekaan KM 9 No 29 Kampus UIM, Telp 0411-588-167 \\ Email : ${ }^{1)}$ suradi.dpk@uim-makassar.ac.id, ${ }^{2)}$ andihaslindah.dty.@uim-makassar.ac.id \\ ${ }^{3)}$ Jamilahhusna193@yahoo.com
}

\begin{abstract}
ABSTRAK
Ikan Bandeng merupakan potensi yang melimpah di Kabupaten Maros dimana pengolahannya masih sangat minim. Salah satu cara pemanfaatannya yaitu dengan melakukan pengolahan ikan bandeng menjadi nugget. Selain sebagai cemilan, nugget ikan juga bisa dijadikan sebagai lauk makanan.Penelitian ini didasarkan pada analisis data tentang kelayakan bisnis terhadap aspek pasar dan pemasaran, aspek produksi dan teknologi, aspek organisasi dan manajemen, aspek keuangan, serta Lingkungan. Nuggetdiolah dengan cara mencampurkan daging giling dengan bumbu-bumbu serta bahan pengikat kemudian dicetak dengan bentuk-bentuk tertentu selanjutnya dilumuri dengan tepung roti (coating) dan digoreng. Dari hasil penelitian dan analisa data keuangan yang dilakukan penulis, diperoleh nilai Investasi (Capital Investment) Rp. 179.900.000, Annual Cost Rp. 262.768.333 dan Annual BenefitRp. 345.600.000, nilai BEP Rp. 143.177.744 dengan memproduksi 3.579 bungkus dengan berat produk 1000 gram/bungkus, harga jual Rp. 40.000/bungkus, BCR 1,66 (BCR>1), dan NPV sebesar Rp. 118.691.592 IRR = 36,3\%, MARR = $19 \%$, serta PBP yang dapat dicapai pada tahun ke 3, Berdasarkan nilai tersebut diatas maka rencana pendirian usaha nugget ikan bandeng layak untuk dilaksanakan.
\end{abstract}

Kata kunci: Nugget, Investasi, BEP, NPV.

\section{PENDAHULUAN}

\subsection{LatarBelakang}

Kabupaten Maros merupakan salah satu Kabupaten yang ada di Wilaya Provinsi Sulawesi Selatan yang terkenal dengan sebutan "Butta Salewangan", yang artinya tanah yang makmur, aman dan sejahtera. Disebut demikian karena wilayah Kabupaten Maros memiliki tanah yang subur, dengan potensi sumber daya alam yang melimpah berupa tanah pertanian yang luas dan subur, perkebunan, perikanan, dan lain sebagainya. Selain itu juga kondisi Kabupaten Maros yang dihuni oleh suku Bugis dan Makassar yang hidup secara berdampingan menjadikan Kabupaten Maros sebagai Kabupaten yang Aman dan Kondusif untuk di kunjungi, sehingga secara tidak langsung mengangkat nilai kesejatraan masyarakat Kabupaten Maros itu sendiri.

Kabupaten Maros sebagai daerah pesisir pantai memiliki potensi pengembangan perikanan darat dan laut yang cukup besar. Untuk saat ini jenis budidaya perikanan yang di usahakan adalah budidaya laut, sungai, tambak dan kolam, ikan sebagai komoditi utama di sector perikanan merupakan salahsatu bahan pangan yang kaya protein. Manusia sangat memerlukan protein ikan karenaselainmudahdicerna, polaasam amino protein ikan pun hamper sama dengan polaasam amino yang terdapat dalam tubuh manusia. Di samping itu, kadar lemak ikan yang rendah sangat bermanfaat bagi kesehatan tubuh manusia. 
Produksi hasil tambak di Kabupaten Maros mencapai 12485,8ton/ tahun, di Kabupaten Maros masyarakat sekitar hanya menangkap ikan bandeng lalu menjualnya tanpa mengolah terlebih dahulu, harga ikan bandeng perkilo gram Rp 18.000, jika masyarakat sekitar hanya menjual ikan bandeng langsung ke pasaran tanpa mengolahnya masyarakat hanya mendapatkan penghasilan yang cukup, sedangkan jika ikan bandeng diolah terlebih dahulu penghasilan yang dicapai dapat lebih menguntungkan, namun sayangnya pengolahan ikan bandeng sebagai produk pangan yang memiliki nilai tambah sejauh ini masih sedikitdi Kabupaten Maros. Oleh karenaitu, peneliti ingin mencoba melakukan penelitian tentang pengolahan lebih lanjut tentang ikan bandeng menjadi produk yang memiliki nilai tambah lebih dan merupakan terobosan baru dalam rangka pengembangan perekonomiandaerah di Kabupaten Maros dibutuhkan suatu penelitian dan pemikiran yang akurat, tepat dan terpercaya mengenai kelayakan usaha yang bertujuan untuk mengetahui apakah usaha ini mempunyai prospek yang layak atau tidak untuk didirikan.

\subsection{Rumusan Masalah}

Berdasarkan latar belakang di atas maka rumusan masalah dalam penelitian ini yaitu Menganalisis layak atau tidaknya usaha nugget ikan bandeng didirikan di Kabupaten Maros.

\subsection{TujuanPenelitian}

Berdasarkan rumusan masalah di atas, maka tujuan penelitian ini adalah Untuk mengetahui layak atau tidaknya usaha nugget ikan bandeng didirikan di Kabupaten Maros.

\subsection{BatasanMasalah}

Agar pembahasan tidak meluas dan menyimpang dari permasalahan yang ada, maka dalam peneliti ini perlu memberikan batasan masalah. Adapun batasan masalah tersebut Pembahasan di tinjau dari berbagai aspek, yaitu : aspek pemasaran, aspek produksi dan teknologi, aspek organisasi dan manajemen, aspek keuangan, dan aspek lingkungan.

\subsection{Manfaat Penelitian}

Adapun kegunaan penelitian sebagai berikut : 1. Bagi peneliti
Peneliti dapat menerapkan bidang keilmuan dan dapat mengembangkan pengetahuan yang didapatnya dalam pendirian serta menjalankan bisnis baru yang prospektif.

2. Bagi masyarakat Kabupaten Maros :

Hasil penelitian ini diharapkan menjadi bahan masukan bagi masyarakat kabupaten Maros khususnya bagi industri kecil menengah (IKM) untuk lebih kreatif dan menjadikan sebagai ide bisnis baru.

3. Bagi pihak lain

Penelitian ini diharapkan dapat menjadi bahan referensi khususnya bagi yang berminat memanfaatkan ikan bandeng diolah menjadi nugget.

\section{METODOLOGI PENELITIAN}

\subsection{TempatdanWaktu Penelitian}

Waktup enelitian berlangsung pada Bulan Januari sampai Februari 2017.

\subsection{MetodeAnalisis Data}

Metode analisis data yang digunakan dalam penelitian ini adalah mengunakan nilai titik impas (BEP), analisis kelayakan usaha (PBP, NPV, IRR ). Berikut adalah metode analisis data yang digunakan :

a. Analisi Break Event Point (BEP) dengan rumus :

$$
\begin{aligned}
\text { BEP (Rupiah) } & =\frac{\text { Total Fixed Cost }}{1-\frac{\text { Variabel Cost/ Unit }}{\text { Penjualan/ unit }}} \\
\text { BEP (Unit) } & =\frac{\text { Total Fixed Cost }}{\text { Harga Jual /unit - Variabel/unit }}
\end{aligned}
$$

b. Analisi Payback Period (PBP) dengan rumus :

$$
\mathrm{PBP}=\mathrm{N} 1+\frac{\mathrm{NPV} 1}{\mathrm{NPV} 1-\mathrm{NPV} 2} \times \mathrm{N} 2-\mathrm{N} 1
$$

c. MenghitungNet Present

Valuedenganrumus :

$\mathrm{NPV}=-\mathrm{I}+\mathrm{AB}(\mathrm{P} / \mathrm{A}, \mathrm{I}, \mathrm{n})-\mathrm{AC}(\mathrm{P} / \mathrm{A}, \mathrm{I}, \mathrm{n})$

Indikasi :

NPV $=$ Positif, proyek dapat diterima

NPV $=$ Negatif proyek ditolak

$\mathrm{NPV}=$ Nol, proyek ditolak

d. Analisis $I R R$ denganrumus :

$\mathrm{IRR}=\mathrm{i}_{1}+\frac{\mathrm{NPV} 1}{\mathrm{NPV} 1-\mathrm{NPV} 2}+(\mathrm{i} 2-\mathrm{i} 1)$

Keterangan : 
$\mathrm{i}_{1}=$ Tingkat bunga 1 ( Discount rate NPV 1 )

$\mathrm{i}_{2}=$ Tingkat bunga 2 ( Discount rate NPV 2)

NPV 1 dan NPV 2= Net Present Value 1 dan Net PresentValue2.

\subsection{Teknik Pengumpulan Data}

Dalam pelaksanaan penelitian ini, pengumpulan data dilakukan dengan cara sebagai berikut :

1. Survei Lapangan (Field Research)

Survei lapangan dilakukan untuk memperoleh data primer dengan menggunakan teknik pendek atan yakni observasi untuk pengumpulan data dengan mengadakan pengamatan langsung di lokasi penelitian serta wawancara terbuka dengan responden.

2. Studi literature dan kepustakaan (Library Research)

Bertujuan untuk dapat menganalisa secara teoritis terhadap masalah-masalah yang berhubungan dengan penulisan dengan membaca skripsi, studi kepustakaan dilakukan dengan membaca berbagai text book, jurnal jurnal, artikel artikel yang relevan, sumber-sumber lain guna memperoleh data sekunder.

\section{PEMBAHASAN}

\subsection{Aspek Pemasaran}

Produk yang akan ditawarkan kepasar yaitu Nugget ikan bandeng. Nuggetikan bandeng merupakan produk yang dibuat dari daging giling dengan penambahan bumbubumbu dengan susunan komposisi berbahan baku ikan bandeng. Nugget dipengaruhi oleh komposisi bahan penyusunnya, teknologi pengolahan, system pengemasan yang baik.

\subsection{Aspek Prduksi dan teknlogi}

Kapasitas produksi yang di rencanakan adalah 30 bungkus / hari selama 24 hari kerja jadi dalam 1 bulan adalah 720 bungkus/ bulan. Kapasitas produksi direncanakan untuk memenuhi kebutuhan masyarakat sekitar lokasi perusahaan, adapun kapasitas produksi yang akan ditingkatkan disesuaikan dengan kebutuhan dan permitaan konsumen.

\subsection{Aspek Organisasi dan Manajemen}

Perencanaan dalam suatu usaha sangat penting untuk menunjang jalannya suatu usaha. Selain perencanaand ibutuhkan pula bentuk organisasi yang terstruktur dengan jelas sehingga dalam menjalankan usahanya juga dapat terlaksana dengan baik, tanpa harus terjadi pekerjaan ganda dalam manajemen tenaga kerjanya.

\subsection{Aspek Keuangan}

Tabel 1. Kesimpulan Terhadap Kelayakan Proyek

\begin{tabular}{|c|c|c|c|}
\hline $\begin{array}{l}\text { Alat } \\
\text { Ukur }\end{array}$ & $\begin{array}{c}\text { Hasil } \\
\text { Pengukuran }\end{array}$ & $\begin{array}{l}\text { Rata-rata } \\
\text { Industri }\end{array}$ & Ket. \\
\hline MARR & $19 \%$ & $12 \%$ & Baik \\
\hline BCR & 1,66 & $\mathrm{BCR}>1$ & Baik \\
\hline $\begin{array}{c}\text { Pay back } \\
\text { Period }\end{array}$ & $\begin{array}{l}3 \text { tahun } 2 \\
\text { bulan }\end{array}$ & $\begin{array}{c}\text { Sesuai Dengan } \\
\text { Target } \\
\text { Perusahan (5 } \\
\text { tahun) }\end{array}$ & Baik \\
\hline NPV & 118,691592 & $\begin{array}{c}\text { NPV }=\text { Positif }(+) \\
\text { Proyek Dapat } \\
\text { Diterima }\end{array}$ & Baik \\
\hline IRR & $36,30 \%$ & $\begin{array}{c}\text { IRR } \\
(\%)>\operatorname{MARR}(\%)\end{array}$ & Baik \\
\hline
\end{tabular}

\subsection{AspekLingkungan}

Pada aspek lingkungan membahas masalah dampak lingkungan di sekitar industri. Aspek lingkungan sangat berarti bagi kelangsungan perusahaan, karena perusahaan tidak lepas dari lingkungan tempatnya berada, sehingga yang harus diperhatikan adalah masyarakat, situasi, kondisi, dan budaya setempat. Kita juga harus memikirkan dampak-dampak yang ditimbulkan oleh pendirian perusahaan tersebut. Pada dasarnya dampak negatif yang timbul akibat aktivitas produksi dari industri ini masih berada dalam tahap ambang kewajaran dan standarisasi kesehatan lingkungan yang ditetapkan, sehingga dapat dikatakan pendirian industri tersebut jika dilihat dari aspek lingkungannya sangat layak.

Pada aspek lingkungan membahas masalah dampak lingkungan di sekitar industri. Aspek lingkungan sangat berarti bagi kelangsungan perusahaan, karena perusahaan tidak lepas dari lingkungan tempatnya berada, sehingga yang harus diperhatikan adalah masyarakat, situasi, kondisi, dan budaya 
setempat. Kita juga harus memikirkan dampak-dampak yang ditimbulkan oleh pendirian perusahaan tersebut. Pada dasarnya dampak negatif yang timbul akibat aktivitas produksi dari industri ini masih berada dalam tahap ambang kewajaran dan standarisasi kesehatan lingkungan yang ditetapkan, sehingga dapat dikatakan pendirian industri tersebut jika dilihat dari aspek lingkungannya sangat layak.

\section{PENUTUP}

\subsection{Kesimpulan}

Dari analisis kelayakan usaha yang telah dilakukan,diperoleh hasilbahwa dalam pemasaran produk usaha nugget ikan bandeng di Kabupaten Maros ditinjau penerapan Bauran pemasaran berdasarkan pada konsep 4P (Product, Price, Place, Promotion). Dari aspek teknologis, proses produksi nugget ikan bandeng menggunakan peralatan yang sederhana. Kapasitas produksi per bulan dari perusahaan sebanyak $720 \mathrm{~kg} /$ bulan dibutuhkan bahan bakuikan bandeng sebesar $30 \mathrm{~kg} /$ harinya dengan 24 harikerja volume produk perkemasan yaitu 1000 gram/ bungkus. Dari aspek SDM dan organisasi, IKM Nugget Ikan Bandeng dipimpin oleh 1 (satu) orang pimpinan, 1 bendahara. Selanjutnya Nugget Ikan Bandeng memiliki 1 tenaga kerja produksi dan 1 tenaga kerja bagian pemasaran. Untuk aspek finansial, dengan investasi sebesarRp. 179.900.000,rencana kapasitas produksi nugget ikan bandeng sebesar 8.640 bungkus dengan harga jual Rp.40.000 /bungkus serta keuntungan yang di peroleh $\mathrm{Rp} \operatorname{Rp} 74.548 .501 .,-/$ tahun, (NPV>0), nilai IRR36,3\%>MARR $19 \%$; BEP/unit sebesar 3.579 bungkus dengan hasil penjualan Rp.143.177.744,- ; serta Pay Back Periodnya dapat dicapai pada 3 tahun sehingga investasi dinyatakan layak

\subsection{Saran}

Dari hasil analisa kelayakan praperencanaan pendirian usaha Nugget di Kabupaten Maros, maka kami menyarankan :

1. Strategi pemasaran yang diterapkan sebaiknya bersifat dinamis, artinya strategi pemasaran harus selalu disesuaikan dengan perkembangan pasar yang ada.
2. Untuk meningkatkan keuntungan perusahaan, perlu ditingkatkan efektivitas, efisiensi dan produktivitas kerja dari seluruh tim menejerial.

3. Melihat dari paparan keseluruhan dari business plan ini khususnya dari akuntabilitas usaha dapat dikatakan bahwa usaha ini layak untuk dijalankan, Prospek yang baik idealnya harus cepat ditindak lanjuti dengan baik.

\section{DAFTAR PUSTAKA}

Amin, Idi. 2012. EkonomiTeknikBahan Ajar. Akademi Teknik Industri Makassar.

Badan Pusat Statistik Kota Maros.2016. Maros Dalam Angka 2016. Kabupaten Maros.

www.kab.maros.go.id. (tanggal 15 maret 2017)

Kandungan ikan.

http://www.ristek.go.id. (tanggal 19 maret 2017)

Kasmir, Jakfar. 2010 dan 2012. Studi kelayakan bisnis edisi 2. Penerbit PT Kencana : Jakarta

Kotlenphilip. 2005. Manajemen Pemasaran. edisi 11. Jilid ; Indeks.

Muhammad danial muchtar. 2012. Diversifikasi olahan jagung ketan (zea mays-ceratina) menjadi dodol jagung di kabupaten maros. Nugget.

http://supermetroemall.com/frozenfood/nugget. (tanggal 19 maret 2017)

Pengertian nugget. http://www.Damandiri.Or.Id/File/Epirospi atiipbbab2.Pdf. (tanggal 19 maret 2017)

Punjangkoro S. 2004. Analisa Jabatan (job Analysis). Penerbit Universitas Sumatera Utara, Medan.

Robert J.K. 2005. Analisis Ekonomi Teknik. Penerbit Andi, Yogyakarta.

Sri Rusmiyati. Budidaya Bandeng Super. Penerbit pustaka baru press.

Suherman, E.2011. Praktik Bisnis Berbasis Entrepreneurship. Afabeta : Bandung

Suliyanto. 2010. Studi Kelayakan Bisnis. Penerbit ANDI. Yogyakarta.

Suwinto. 2011. Studi kelayakan pengembangan bisnis. penerbit Graha ilmu. Yogyakarta 